\title{
Aftershocks and (Un)belongings: Reflecting on Home Strike'
}

\section{Alexandra Kokoli and Basia Sliwinska}

In this dialogic chapter, we reflect on our collaborative curation of an exhibition that explored domesticity from feminist dissident perspectives. Featuring work protesting the changes to policy concerning domestic violence in Poland (Malgorzata Markiewicz), subverting, through craft, women's maintenance of the home as both dwelling and ideal (Su Richardson), unpicking maternal subjectivities while staging a confrontation between feminist and modernist approaches to art history (CANAN), and unsettlingly recasting the home as a site of violence and resistance (Paula Chambers), Home Strike (l'étrangère, 2018) is revisited as both an unfinished inter-generational and transnational project critiquing and defamiliarising the home, and an opportunity for reflection and exchange on the curators' own lived experiences of migration and patriarchal regimes of space. Personal meditations on (un)belonging, temporary habitats and object attachments are interspersed with critical observations on migration, xenophobia and the neoliberal demand for mobility, particularly in the case of cultural workers. As well as (a) correspondence and dialogic reflection on shared preoccupations, what follows is an exchange of letters working through the aftershocks of our co-curation of an exhibition and opening up new strands of thinking and research into projects yet unrealised. The epistolary form was adopted as a practical and equitable record-keeping of our exchange, but also for its rich tradition in feminist politics and thought: as Margaretta Jolly (2008) eloquently demonstrates, in the Women's Liberation Movement correspondence both charted the emergence of a new consciousness and sisterly alliances, and became a lab for the development of alternative ways of thinking and engaging with one another. Following recent feminist experimentation, we aspire to occupy the space between 'letter-writing as a formal convention' (Meskimmon, 2014, 31) and a dialogical critical feminist methodology of 'engaged essay-making' (ibid, 29).

22 October 2018

Dear Alexandra,

I am writing with and to you from my home or one of many homes I inhabit. When we collaborated on Home Strike, the exhibition in l'étrangère in London, we revisited the concept of home, its visual and material representations, and its social and cultural embodiments. We set out to explore the active disaffirmation of contended and nurturing domesticity reviewing the 1970 s feminism and analysing its currency in contemporary art practice. This dialogue through curation concerned domesticity from feminist dissident perspectives but also our own lived experiences of migration and personal mediations of mobility.

In An Ethics of Sexual Difference (1984) Luce Irigaray talks about mucous subjectivity, a mediating substance for thinking about the female. Similarly, Hélène Cixous (2005) writes about the gendered body when discussing écriture feminine as a practice of 'writing from and of the body'. Hilary Robinson $(2006,98)$ suggests that a mucous-based subjectivity does not follow the rules of the solid, it defines someone with porous boundaries. This mucous 
subjectivity resonates with myself and my body with/in space. The moment I left the country I was born in, Poland, my body and so subjectivity, have been subjected to perpetual becoming with/in space. First I moved to the Netherlands, then went towards Poland and in 2007 towards the UK where I am at home at the moment of writing this letter. To quote the title of the edited collection of essays by Sara Ahmed, Claudia Castañeda, Anne-Marie Fortier and Mimi Sheller (2003) since then I have been 'uprooted and reground', inhabiting and moving across national and diasporic locations and experiencing migration in relation to home and belongings and these, in turn, being subject to change because of the conditions of movement, configurations of placement and an individual. I am a subject of affect in my mobility. 'Being grounded is not necessarily about being fixed; being mobile is not necessarily about being detached.' (Ibid: 1) I enjoy this stage of liminal and transformative plasticity but also possibility. I am inserting myself in many spaces when I perform the 'home' seeking my place of origin or perhaps doing the 'homing', in the sense that I navigate a ship, an aircraft, a satellite, or simply myself. Cixous would suggest a mode of and for production, 'works of being'. I am hoping our epistolary exchange in the form of this mobile letter, extending collaborative curation, between text and discussing techne (craftsmanship and art practice), will allow us to further explore the home and habitat in the context of mobility as an opportunity and an imperative but also precarity. Each of the women artists featured in the exhibition, Paula Chambers, CANAN, Małgorzata Markiewicz and Su Richardson approach home differently but usually as an embodied battleground. They subvert domesticities within aesthetics and politics. How do they defamiliarise the home?

Today I sold my red bike I used to commute to the train station from where I take the train to get to work. I also used it to go to the local market to buy fresh fruit, flowers and sometimes cheese. On one hand it upset me, on the other it uprooted me, which was quite liberating. I feel I am mobile again. I am not yet sure towards where or what.

With love to you,

Basia

26 October 2018

Dear Basia,

Your 'letter' made me realise how much we took our shared migrant backgrounds for granted. We are two of many in academia, and of very many more in the so-called cultural industries, sustained as these are by countless hours of under- or unpaid labour that migrants often perform. The artworld's 'dark matter' (Scholette, 2011) is profoundly gendered and over-represented among social groups already primed for financial and professional insecurity. It was a privilege to work with you on Home Strike, in all senses of the word. I both enjoyed and learned lots from working together. We and the artists we invited were financially and infrastructurally supported by a commercial gallery with a very sympathetic and knowledgeable director, Joanna Gemes; if the burden of fund-raising were added to the project it wouldn't have materialised in the same timescale and may not have 
happened at all. The two of us were also enabled by our (relatively) secure academic employment: it meant that we could cast our labour towards the exhibition as institutionally supported 'research activity'; at the same time, increasingly unmanageable demands of institutional maintenance, in addition to normal teaching and administrative duties, has meant that Home Strike went the way of much of our research, pushed into evenings and weekends, including a particularly memorable long, cold Sunday in the gallery.

I am intrigued by the notion of 'uprooted and reground'. On the one hand I tend to think of my - and everyone else's - national provenance as a mere accident of birth: of course our cultural context shapes us, as does the experience of life as an immigrant, but so do other factors that are not, or not necessarily, contingent upon these conditions. (By the way, when I shared this view in a class I was teaching, a male student from Southern Europe was left speechless with rage; it was one of the few times I worried that a verbal disagreement might escalate.) On the other, the phrase accurately captures neoliberal precarity, not as an event but a rhythm inflecting life in both the everyday and in macro-scale; I want to think about uprootings and regroundings in literal terms too, especially but not only in reference to the installations of Paula Chambers, but l'll come back to this in my next letter.

The epistolary form feels odd in its intimate formality (I haven't written a letter in months and have one single friend left who prefers to communicate in this outdated medium) but also apposite in forging a special place for an exchange that otherwise may not have happened. We've been exchanging emails about plans to revisit and expand the show and have briefly discussed how we thought it went face to face, but otherwise there's been little opportunity for reflection. Reflection with no immediate outcome feels like an indulgence. These days, letters seem to me to occupy a precarious place between the public and the private: although originally intended for the specified addressee, we are now more likely to come across them in museum collections or digitally archived online, as historical documents rather than agents of exchange. Writing to one another in this way-and for publication - made me think of 'public intimacy' in all its connotations of inappropriateness but also as a challenge to the bubble of privacy as constitutive of bourgeois individualism. Giuliana Bruno (2007) proposes the term to describe the experience of art and museum collections as memory screens by bodies on the move, in public, but absorbed in private thought. The emergence of the sphere of domesticity has had everything to do with the division of the public and the private and its oppressive mapping onto gender roles as well as its weaponisation in the social reproduction of sexual normativity. In this sense, our rulebreaking quasi-correspondence performs some of the aims of the exhibition, while also reflecting on it.

Would it be self-aggrandising to think of our correspondence device as an evocation of the Women's Postal Art Event, aka Feministo, for which some of Su Richardson's work that she showed in Home Strike was created? I vividly recall my first visit to Monica Ross's studio in Brighton in 2000: a core Feministo participant and co-instigator of its follow-up Phoenix, Monica was keen to stress the vibrancy of 'correspondence' as a shaping condition of the women's postal art event beyond the exchange of small hand-made objects by post. After all, postal correspondence was motivated by the common recognition of many correspondences among the lives of the participants, not necessarily straight-forward commonalities but opportunities for making connections and, ultimately, building networks 
of solidarity. As many others have noted, Feministo was borne out of consciousness-raising, a widespread if not defining activist practice of second-wave feminism, which was given visual and material form. Feministo was a labour of love, friendship and sisterhood, while also seeking to parse and dismantle the naturalised expectation of feminine nurturance and the casting of housework and care duties as 'labours of love'. We're still caught in the same tangles and I don't know how this makes me feel.

'Love'/love, Alexandra

29 October 2018

Dear Alexandra,

I will start by saying I looked forward to this moment when I can re-read your letter and respond to it. Not in haste, in between countless work emails, Excel spreadsheets with budgetary codes and too little time to prepare my teaching I so enjoy doing. The teaching and the ethos and ethics of education have now been eclipsed by bureaucratic and administrative labour required and expected by neoliberal and late-capitalist institutions we work for, which, paradoxically, are still called Universities. This is a topic for yet another exchange of letters. Here, I would like to start by responding to your observation regarding our correspondence device as an evocation of Feministo.

This reciprocal exchange is indeed an opportunity to make connections and build networks of solidarity. I would like to share a story with you. As you know, I was born in Poland which was at that time bordered off the 'Western' world by different ideological structures of division such as the Berlin Wall or the Iron Curtain. 'Western' consumer products were nearly impossible to obtain. However, they were often shared via postal correspondence by relatives or friends who fled the country towards the USA. One of my Mother's friends was regularly receiving such correspondence including letters but also desirable goods. I remember one package that arrived shortly before pre-1989 Christmas. There was a deliciously fragrant bar of soap, which my Mother's friend, while visiting us, put on our kitchen table and cut in four to share it with her three female friends, including my Mother. This gesture of sisterhood and friendship enacted through this gift was a labour of love and did not necessarily concerned nurturance and care duties. Mauss (1924) conceptualised the gift as a free and obligatory phenomenon, which involves a triple obligation of giving, receiving and reciprocating. Economy of the gift is founded upon feminist principles of generosity and bonding but also hospitality. The soap wasn't a necessity but an indulgence. It was also, in the eyes of a few years old girl who I was then, a celebration of womanhood and subjecthood and not the objectification of woman or her instrumentalisation in the context of normalised domestic structures of maintenance, gendered violence and oppression. This quarter of a bar of soap left at our home embodied the denied and reclaimed self, and its celebration, the right to one's body in every sense of the world. It was an act of self-care, an intimate gift oriented towards bodily well-being. Strangely, it makes me think of Małgorzata Markiewicz's video shown at the exhibition, in which she unpicks the structure of 'home', the bourgeois expectation to nurture and subordinate, and deny 
one's pleasure in favour of satisfying the needs of others (Fig. 1). In the video The Resistance Kitchen (2017) the home and the domestic become the country, Poland, entangled in national right-wing politics overpowering the female body and governing it by imposing the rights and limitations, often in violation of human rights. Markiewicz critiques the efforts of the Polish government to further restrict access to abortion, pre-natal care and contraceptives in a country, in which the abortion law is already among the Europe's strictest. Ewa Ziarek (2007) explains the pathologies of Polish nationalism referring to the violence perpetrated against Jews in the WWII. When my Mother and her friends were sharing the bar of soap, abortion in Poland was, paradoxically, legal. Poland welcomed capitalism and neo-liberal economy and women lost the right to their bodies.

You are right in saying that this epistolary exchange gives us an opportunity to reflect and this reflection concerns looking back but also looking at ourselves, as though in a mirror, at our shared migrant backgrounds. Even though I am typing these words I would much rather prefer to write them on a piece of paper, feel and smell the paper, and hear the line drawing the letters rather than the sound of the keys of my keyboard. This electronic exchange furthers the notion of public intimacy, which you raise and the division of the public and the private, and the reproduction of sexual normativity. It reminds me of Arendt's (1998: 57-58) observation that bodily experience in space makes the world accessible to all. In The Human Condition Arendt also discusses the transition from the classic Greek understanding of the human condition based on three activities: labour, work and politics towards the modern condition, which she believes is based only on one activity: labour. Such unequal distribution (or lack of) of activities conditioning humanity is a threat to all life as labour is no longer seen as a relationship one has with their body and the bodily functions of others.

Being a migrant my bodily labour is embodied in the experiences of departing, arriving, being in transit and being here and there, and in between. I am sitting in my space (in fact it belongs to the bank with which I signed a Faustian pact giving me access to a place, provided I remain in my relatively secured employment and pay off the debt). It is a room but I do not consider it a physical place, rather space granted to me as my own which I carry with/in me. This mobile space is grounded by objects although some of them are mobile enough to be uprooted with myself. Even though the objects that live with me 'behave' on the contrary to some of the objects inhabiting Paula Chambers' works, there is one, which moves and migrates, or perhaps is uprooted and reground, and which reaffirms your observation which I share that we are shaped by factors not necessarily contingent upon our national provenance. Her name is Luna and she is a mannequin, a doll, an inanimate object, my other self? Today she sits under a fig tree, on an old Singer sewing machine which belonged to my grandmother and which I brought with me from Poland to the UK to feel more at home. Sometimes Luna enjoys being close to the bookshelves, sometimes she sits close to a sofa. She moves around my domestic space as she pleases, claiming it and reclaiming. She reminds me of Paula's brides and women with guns, relocating themselves, context dependent. Luna and Paula's female figures embody Ewa Ziarek's (2002: 6) concept of the 'ethos of becoming', 'first, the task of resistance to power and, second, the transformation of the negative thought of resistance into a creation of new modes of being.' Paula's makeshift feminist armaments resist and offer new figurations of femininity, which counter domestic ideologies and violence of maintenance labour. They have the agency and 
they subvert structure(s) of domestic oppressions. They reflect Ziarek's ethics of becoming, which 'poses and redefines the question of agency and freedom of historically constituted subjects: no longer seen as an attribute or a possession of the subject.' (Ibid: 15) They are their own subjects and they claim the space of their own.

Alexandra, thank you for this exchange and generous sharing of yourself. It has always been a pleasure and privilege to work with you. I learn so much and I grow through this gift of reciprocity. I feel a possibility of a different discovery of myself.

Love outwards to you, Basia

Oakland Park, Johannesburg, 10 November 2018

Dear Basia,

I'm writing from Johannesburg, where I spoke the conference Mistress Pieces (University of Johannesburg, 8-10 November) on the alternative domesticities of the Greenham Common Women's Peace camp. Mobility (as freedom and as a neoliberal expectation of labourers) and claiming space are always on my mind but, from where I'm writing to you, they've become aggressively defamiliarised. Johannesburg is naturally gorgeous and yet also such an extreme example of what

Rowland Atkinson and Sarah Blandy call 'a securitised residential landscape' $(2017,156)$. The city's middle-class neighbourhoods remain not just out of reach but out of sight, hidden behind high brick walls topped with lengths of razor wire or sometimes electrical fencing. From where I'm sitting, Atkinson and Blandy's sociological study morphs into a gothic novel: they identify 'a more prickly outward appearance [...] intentionally intimidating to those with ill-intent, perhaps, but also generating a wider unease' (158) in visitors like myself, and even inhabitants who find themselves on the outside of these domestic fortifications. I am driven around in cars and vans with my fellow, mostly foreign, conference delegates, the conviviality of the inside contrasting uncomfortably with the imagined dangers lurking outside, from which we remain protected. The city opens itself up little by little, in fits and starts, and when it does it offers warmth, knowledge, hospitality and even friendship. But, in transit, I am almost overcome by the (sub)urban landscape, a jacaranda-lined 'solidification [...] of fear' (158). Even the beauty of the purple jacarandas is marred by the realisation that these non-indigenous trees are water-hoggers and exacerbate the dryness of the soil, killing off other plant species as a result (Denny-Demitriou 2010). The problem, of course, is not fundamentally architectural, nor aesthetic: 'physical space and its structure is important in thinking through connections to a broader social politics which is increasingly antagonistic to shared forms of provision and insurance and more predisposed to private solutions and services' (Atkinson and Blandy, 2017, 157). Peaks in domestic securitisation mark the spots where the social fabric has worn threadbare.

On a positive note, the trip reminded me again of the smallness of the world I notionally and physically occupy: even my everyday understanding of globalisation mostly relies on a mere 
handful of - admittedly influential - currents of mobility and (usually unequal) exchange. Trawling through the journal African Arts, I found an article on Nollywood (the everexpanding Nigerian film industry, including co-productions with its West-African neighbours), and the ways in which artists like Zina Sar-Wiwa have analysed its representation of domestic space as 'not simply settings for melodramatic performances but [...] a microcosm for the "crisis" in social relations' (Makhubu, 2016, 58). While Makhubu writes of social crises in Nigeria, popular culture inflected by the pseudodemocracy of social media brims with diverse stagings of 'crises' of different kinds at the intersection of the public and the private. Paula Chambers has identified the figure of the gun-toting woman as a real and imaginary visualisation of such intersections, and makes objects out of their images sourced on the internet. Real and imaginary, grotesque and idealised, alone, in groups, and with their children, Paula's women in guns are far from lifesize, approximating instead the scales of mantle ornaments. Instead of decoration, they make up an infestation of sorts for her unsettling barricades, cobbled together out of fragments of found or occasionally stolen furniture. Domestic Front (2016) (Fig. 2) lurks in the gallery space carrying with it an unsettling out-of-place-ness and poses the even more disturbing question: under what circumstances would you build a barricade at home? It is interesting that the not quite random nor obviously systematic placement of the figures on the barricade appears to provide a model for Feminist Clutter (2018) (Fig. 3), another of Chambers's disruptive interventions in and occupations of space. Clutter speaks of objects out of place and out or order, crossing boundaries, not knowing their place. Disruptive agency is shared and, in being shared, becomes augmented between revolting subjects and disobedient objects. Here, things are enlisted in feminist struggle, while the aggression against which the highly securitised homes I saw in Johannesburg are guarded is shown to emanate from within the domestic sphere, not (or not merely) spilling into it from the outside.

If we were to revisit Home Strike l'd like to include some textile works by Senzeni Marasela: something from her Theodorah comes to Johannesburg series, a durational project led by performance and with manifestations across different media including photography and textiles (FIG x). Marasela assumes the persona of Theodorah, a Lesotho woman married to Gebane, while also embodying the experience of many black South African women who were deprived of their husbands for indefinite lengths of time through political imprisonment, activism (which often led to imprisonment or exile), and labour migration. Inspired by Njabulo Ndebele's novel The Cry of Winnie Mandela (2004), a South African reworking of Penelope's painful wait for Ulysses, Marasela invents the character of Theodorah who makes the long journey to Johannesburg in search for her husband, evoking all its implications: leaving children behind, loneliness, uncertainty, guilt, and frustration. Such monstrous separations were borne out of Apartheid violence in its quieter but arguably more sustained and efficient manifestations than the widely broadcast murderous suppression of protests and uprisings. Apartheid divisions required more than highly securitised homes: by forcing so many into migrant labour, exile, and prison, they put enormous strains on personal relationships and effectively gutted the family lives of whole communities. Theodorah and women like her found themselves on 'journeys into strangeness' by the apartheid migration system (Kouoh, 2015), forced into a state of perpetual homesickness. In one of the iterations of the Theodorah project, the photographic series Ijeremani Lam (2013), Marasela embodies Theodorah in the manic (in)activity and 
awkwardness of public waiting: she is looking for her husband, from whom she has long been separated, in a unfamiliar and hostile city. Other than subtle but noticeable changes in comportment, Marasela's embodiment of Theodora relies on a single and powerful prop, a dress that identifies her as a married woman from Lesotho, a 'Seshoeshoe', which she has committed to wear for a period of five years (Greslé, 2014). The dress, a version of which is in the art collection of the Apartheid Museum, is recognisable to all South Africans as a material shorthand for marriage but also for these cruelly protracted, involuntary separations. Rather than a fictional character, Theodorah's elusive husband Gebane is a 'phantom', who is keenly sought only so that Theodorah can finally liberate herself from him (Greslé, 2014). At the 'Mistress Pieces' conference, Marasela spoke briefly about her decision to remain in the dress whose faded red colour evidenced the authenticity of her durational performance. Later, over drinks, she laughed over the discomfort that her insistence to wear this dress still causes at art world parties, to which she's invited and celebrated as the art 'mistress' that she is and which she also partly spoils, like a true feminist killjoy (Ahmed, 2010).

How could we best show Theodorah in Home Strike 2.0? The dress is powerful but its material code is not as easily readable outside South Africa. Marasela's party anecdotes unpick the seams of complicity and contradiction upon which so many of our professional (and maybe not just professional) transactions rely. A commission rather than a loan might be the thing.

Alexandra $x x$

12 December 2018

Dear Alexandra,

In your letter you mention being a visitor in Johannesburg. I have just come back from Melbourne, where I organised a conference session focused on feminist activism, social injustice and contemporary art. It made me rethink many issues in relation to space, domesticity and home, one of them being the context, which is often neglected and which makes art pieces, objects, rituals, values body language and so on not easily readable, as you have noted, outside of country of origin or 'birth'. This journey also reaffirmed my interest in the figure of the visitor in relation to the private and the public. Among many, arriving with me on the plane and those already in Australia settling in or having settled already, I was a visitor to a colonised country, in which the agency of indigenous people has been severely compromised also by practises of home making, yet another form of colonisation. I will come back to this point later in this letter. I have realised I am a visitor not only when I travel outside of the UK but also living in the UK, where, even though I am a permanent resident or have what is now called 'settled status', I am still considered a passing visitor. Would naturalisation change this status? I doubt it. I often come across the expression 'occupying space', which in itself suggests violence in relation to space - claiming space, taking space, making your own and rarely shared. Is home making about building fortresses? Is this yet another neoliberal and late capitalist strategy to individualise what should be shared, appreciated and lived as common? This is not what we have discussed in 
this exchange of letters but this brutal and often ignorant spatial possession disrespecting cultures and values is something that I wish to address in Home Strike 2.0. It seems to me the potential inclusion of Theodorah is a prelude to acknowledging the dispossession of others and the colonisation of the private through the public or the indigenous through the occupant(s). Being European I acknowledge that often I have been ignorant to my white privilege and I grew up admiring what was mythologised in Poland as 'Western' and yet blind to its culture damage to what is pejoratively termed as 'other', 'different', 'exotic' or 'primitive'; so many names and terms to name 'the enemy' out of fear of difference. In my teenage and early adult years I arrogantly neglected dispossessed others and failed to always welcome the other with respect and partnership. An expanded Home Strike 2.0 would for me be a gesture of a heartfelt apology and a commitment to acknowledge intergenerational traumas caused by unequal (on what grounds?) divisions of space.

You talk about alternative domesticities, boundaries and disruptive agency, which make me think of Sera Waters's textile work, which I came across when in Melbourne, focused on hauntings in settler colonial homes. Those 'genealogical ghostscapes', as she calls them, define the places of traumas and Australian condition of living in the aftermath of colonialization. What we often discuss in the context of comforting tradition of home making, might in fact be seen as a brutal violation of private space not appropriate or 'correct' if assessed from imperial perspective. The cushions, curtains or blinds, imported interior design rituals aimed to beatify (if only) and gestures of home making, most often performed by women, serve to reinforce colonial structures precisely through the comforting traditions of home making, the quite particular aestheticisation and culturalisation of space. The 'home' and activities of the domestic space are significant when considering setting up a 'new' home. This transfer of homeland from centre to periphery and the recreation of space was a particular duty of women who were at the forefront of enforcing imperialist values, let alone in Australia. On one hand this settling down is privatised and often accompanied by feelings of isolation and separation, on the other the work of domestication signifies the settling of land in which a new home appropriates intimate spaces and becomes a surrogate for the centre with claims for ownership. Rosemary Marangoly George in Politics of Home (1996) draws attention to relocations and domestic spaces becoming the centre of subjugation of 'the natives'. This disposition of power and the oppressive practice of domestication and domestic management also demonstrates the self-affirmation of colonial women and further production of class and race distinctions. This multiple understanding of home, produced as what Avtah Brah called 'multi-placedness' is complicated in Waters's works.

The artist produced a series of camouflage cloaks, sewing and stitching a story of her female ancestor Wilhelmina, a home-maker and a hunter. She traced Wilhelmina's photographs in The Nest family album, dated mid to late 1920s. Referring to them through the cloaks complicates the gendering of settler colonialism by portraying Wilhelmina as a matriarch, protective mother, and wallaby hunter. (Waters 2018) At that time hunting was not only a pastime but it served for clearing or extermination purposes particularly around pastoral properties and in the current Little Dip Conservation Park in South Australia. Waters's ancestors used to camp in this area surrounding what formerly was known as Robe. Wilhelmina and her family, in Waters's words, were hunters and hunted. They survived two world war periods and fought for their lives. The brutality of their survival made them 
prioritise themselves. Waters's cloaks depict this dual status and the violence of their livelihoods. Boring Conversations \#2: Cloak of Invisibility (2016) (Figs. 4 and 5) and Camouflage Cloaks for Invaders: Robe (2016) (Fig. 6) raise issues around the political potential of domesticity through the lens of colonialism. Waters explores how colonial powers operate within the intimate space of home and how they disavow agency. The Camouflage Cloak for Invaders: Robe is child-size cloaks painstakingly hand-stitched from materials to which Wilhelmina would have had access: kangaroo pelts, cotton, leather and heavy duty army-issue canvas bags. They are 'care-fully' fabric lined to provide comfort and warmth, which references school robes made by mothers for their children during wartime. These cloaks act as protective wear which could be used as camouflage in the Australian bush to hide from predators. They are also 'creations of sutured animal pelts, re-structured and re-purposed for family proportions and security'. (Waters 2018) Those animal hides on one hand protect the vulnerable, on the other make the coloniser invisible. The heavy fabrics used are juxtaposed against softer materials applied for the other cloaks, Boring Conversations \#2: Cloak of Invisibility produced from towels, cotton, lycra and felt. Waters's concept of 'ghostscapes' acknowledges the metaphorical haunting in settler colonial nations. The artist explains that 'in Australian history 'ghosts' are the repercussions of disavowal', denying the 'brutal truth(s)' of colonisation. (Waters 2018). There is a lot to be said about those works, the historical presences and absences and homes as places where the denial of responsibility for unrecognised pasts is reproduced, and I hope we can expand on this in the exhibition. Through domestic materiality, stitching, embroidery and various textile practices Waters engages with inherited patterns of colonial home making, the gendered hand-made and home-craft practices passed through generations. Interestingly, the artist makes references to the concept of care, which allows her to expose and unsettle the comforting textile traditions as unhomely, 'discomfiting' and uncaring but also express hope for reconciliation and taking responsibility.

Alexandra, I hope that Home Strike 2.0 will offer us an opportunity to take responsibility for domestic disruptions on many levels and acknowledge home making also as a pervasive form of colonisation, violent domestic practice embodying fear through territory making and marking. The artists we brought together in Home Strike 1.0 act, often through repetitive crafting, sculpting, filming, making. This intense tactile labour exposes brutal constructs within the home (understood very broadly) but also identifies the need for ethics of care when expressing disobedience through unsettling eroded spectacle of feminine domesticity. Those gestures show incredible force and power behind anarcho-feminist sensibility and practice of dissent and disruption.

Love to you,

Basia $x$

18 December 2018

Dear Basia, 
I'm so excited by the idea of Home Strike 2.0 as an engine of self-reflection, recognition of privilege, and acknowledgement of responsibility, as well as plans for the next, expanded iteration of the exhibition we curated together. Like yours, my position in relation to white privilege and Western colonialism is complicated. As a Greek, assuming that I descend, in some way, from the inhabitants of the city-states of Athens and their influential frenemies, I must bear some responsibility for the idea and early practice of imperialist expansionism, and the foundations of cultural racism. On the other hand, growing up my relationship with the 'West' was almost as distanced and romanticised as yours in Poland; we still referred to 'Europe' as a far way place (separated from Greece by Yugoslavia, Bulgaria, and Albania), substantially richer and more civilised than 'us'. My whiteness is neither self-evident nor stable: some years ago in Los Angeles I requested a Spanish-language book in a branch of the biggest book sellers in the country, and experienced, for a brief moment, what it feels to be classified as Hispanic on American land that until 1848 belonged to Mexico. In LA I did everything wrong: I walked where white people are expected to only drive, I took public transport, I talked with strangers (and the only strangers who would talk to me were people of colour). Walking around the Staples Centre past 9pm, I saw (mostly Chicano) families with small children and was reminded of my own childhood in Thessaloniki, where I and my peers were happily included in the social lives of grown-ups. I recalled feelings of amazement and pity at the exotic idea of a bedtime, which appeared to so strictly regulate children's existence in American movies. At the end of each day in LA, of course, my privilege would be reconfirmed by my accommodation arrangements.

I'm now here in Britain as a legal immigrant, as settled or unsettled as most of the parents I meet at the gates of my children's school. I've been here for a very long time but my accent will never go away and it hurts whenever my utterances are met with narrowed eyes of (feigned, I imagine) incomprehension. This happens frequently in my exchanges with people I've never met before, although rarely in London. Is their surprise at my accent an indication that I otherwise fit in? Do I really? And what does it mean to fit in in a place as diverse as London? I am reminded of the Seinfeld episode 'The Visa' (season 4, episode 17), where George Costanza, haplessly punching above his weight, approaches a beautiful Chinese American who turns out to be a lawyer with a wide-ranging portfolio: 'Divorce, patents, immigration and naturalization.' Taking advantage of Jerry Seinfeld's absence, George attempts to cast himself as the funny man of the group and quips: 'What is that, immigrants come over, you show them how to act natural?' (Seinfeld Scripts, 1989-1998). The episode ends with the deportation of Babu, a Pakistani restaurateur who loses his business following Jerry's bad advice, and then also his US visa when Jerry fails to sponsor him as he had promised to do. Laughing through the tears...

Another proposal for Home Strike 2.0: the artists' book Cultural Tips for New Americans by Jeff and Alina Bliumis, a compilation of advice for new arrivals to the US on how to 'act natural'. Partly researched from a range of unofficial sources and partly crowd-sourced from fellow foreigner friends, the book includes tips such as the interpretation of an offer of gum as a subtle hint that someone has bad breath, and thus the offer should always be accepted: the condition of 'not fitting in' is holistically and phenomenologically defined, spanning all senses and sensibilities by offending both. The project involved the installation of posters with tips onto phone kiosks and stickers in various places on the Bowery and in Chinatown and Soho in May 2011, an exchange of the book for further tips by resident aliens, and led 
on to the exhibition Cultural Tips takeaway at Toomer Labzda Gallery, New York. Executed at a time when the US was less of a hostile environment for immigrants than it is at present, when babies and children are forcibly separated from their parents, held in unsuitable and traumatising conditions and occasionally left to die (Graham-Harrison, 2018), Cultural Tips captures the low-level hysteria of 'what it means to be an American' with humour and irreverence, while outsourcing the work of defining it to immigrant and transient populations. Like housekeeping, figuring out what it means to be an American is a dirty job so immigrants have to do it. In her solo work, Alina Bliumis delves deeper into the semiology of nationhood focusing particularly on how nature is co-opted in its service: Amateur Bird Watching at Passport Control (2016-2017), a series of 43 prints, features birds sourced from the passport covers from countries across the world. In his catalogue essay, Boris Groys (2018) reflects:

[...] the common characteristic of all these birds is the fact that they are local - be it a pelican from Barbados or a parrot from Dominica. All these birds are prisoners of their territories. Do they ever dream to become free, to migrate, to visit different countries - and not only to draw always the same circles over the same territory? We do not know it. But if the birds have these dreams it is the citizens of the states that have images of these birds in their passports who realize these dreams - at least in symbolic terms. Thus, even if a parrot remains on Dominica and a pelican - on the Barbados the passports with their images have a chance to be checked at the airports all around the world. Whatever can be said about the migrants one thing is sure: they realize their birds' dream of flying.

I find the image with which Groys ends beautifully poetic but also in need of much qualification. Some passports hinder rather than enable their holders' lines of flight; and it is often, ironically, the dreams of the most exotic of birds that remain unrealised due to the political and economic status of the countries that have chosen them as their emblems. As Marina Warner (2000) noted in reference to female goddesses and other gendered archetypes, giving form to big ideas can be a very mixed blessing.

I'm not sure if we'll be in touch again before the holidays so I feel I should wish you a Merry Christmas. As a lapsed Greek Orthodox Christian and committed atheist since the tender age of six, I don't give much credence to such holidays, though I remain curious about those of other religions. Nevertheless, it bears repeating that the main characters of the nativity narrative were all forced to travel away from home for a compulsory census ordered by a European empire and, as a result, found themselves homeless and vulnerable in a strange place. Rather than love, which seems to translate too seamlessly into a consumerist gift transaction, compassion in response to displacement should be recognised as the true spirit of this much exploited holiday.

In compassion and solidarity, always, Alexandra $x x$

\section{REFERENCES}


Ahmed, Sara (2010), 'Feminist Killjoys (And Other Willful Subjects)', The Scholar and Feminist Online, 8.3. http://sfonline.barnard.edu/polyphonic/print_ahmed.htm. Accessed 1 March 2019.

Ahmed, Sara, Castañeda, Claudia, Fortier, Anne-Marie and Sheller Mimi (2003) Uprootings/ regroundings. Questions of home and migration. Berg: Oxford, New York

Archey, Karen (2016). 'Women's invisible labor and the art world'. e-flux conversations, https://conversations.e-flux.com/t/womens-invisible-labor-and-the-art-world/5430.

Accessed 19 December 2018.

Arendth, Hannah (1998) The Human Condition. Chicago: The University of Chicago Press Atkinson, Rowland, and Sarah Blandy (2017) Domestic Fortress: Fear and the New Home Front. Manchester: Manchester University Press.

Bliumis, Alina, and Bliumis, Jeff (2011) Cultural Tips For New Americans. New York: Toomer Labzda Gallery.

Brah, Avtah (1996) Cartographies of Diaspora: contesting identities. London: Routledge Bruno, Giuliana (2007) Public Intimacy: Architecture and the Visual Arts. Cambridge MA: MIT Press.

Cixous, Hélène [1998] (2005) Stigmata: Escaping Texts. London: Routledge

Denny-Dimitriou, Julia (2010) 'They're beautiful, but jacarandas can do harm, warns expert', News 24: The Witness', https://www.news24.com/Archives/Witness/Theyre-beautiful-butjacarandas-can-do-harm-warns-expert-20150430. Accessed: 30 November 2018.

George, Rosemary Marangoly (1996) The Politics of Home: postcolonial relocations and twentieth-century fiction. Cambridge: Cambridge University Press

Graham-Harrison, Emma (2018), 'Anger grows after death of Guatemalan migrant girl held in US', Guardian, 16 December. https://www.theguardian.com/world/2018/dec/15/angergrows-death-guatemalan-migrant-girl-held-us. Accessed 18 December 2018.

Greslé, Yvette (2014), 'Senzeni Marasela: "I remind them of their own waiting"', https://writinginrelation.wordpress.com/2014/09/14/senzeni-marasela-i-remind-them-oftheir-own-waiting/. Accessed: 1 March 2019.

Groys, Boris (2018) 'What do the birds dream about?', Political Animals (catalogue), Aperto Raum, Berlin, http://www.alinabliumis.com/amateur-bird-watching-at-passport-control/.

Accessed 18 December 2018.

Irigaray, Luce [1984] (2004) An Ethics of Sexual Difference. London: Athlone Press

Jolly, Margaretta (2008) In Love and Struggle: Letters in Contemporary Feminism. New York: Columbia University Press

Kouoh, Koyo (2015) 'Senzeni Mthwakazi Marasela: Profile of 2015 FutureGreat Artist', ArtReview, March.

Makhubu, Nomusa (2016) "'This House is not for Sale": Nollywood's Spatial Politics and Concepts of "Home" in Zina Sar-Wiwa's Art'. African Arts, 49:4, pp. 58-69. https://www.mitpressjournals.org/doi/pdf/10.1162/AFAR a 00314. Accessed: $\quad 30$ November 2018.

Mauss, Marcel, [1924] (1990). Gift: The Form and Reason for Exchange in Archais Societies. New York: W W Norton

Meskimmon, Marsha (2014). 'Epistolary Essays, Exilic Emergence and Ephemeral Ellipses... Some Tentative Steps Towards the Creation of a Shimmering Stage for Critical, Corporeal, Collaboration', in Marsha Meskimmon, Astrid von Rosen, and Monica Sand (eds.), Dance as 
Critical Heritage: Symposium Report 1. Gothenburg: University of Gothenburg Press, pp. 2748.

Ndebele, Njabulo (2004). The Cry of Winnie Mandela: A Novel. Banbury: Ayebia Clarke.

Plonowska Ziarek, Ewa (2002) An Ethics of Dissensus: Postmodernity, Feminism and the Politics of Radical Democracy. Stanford: Stanford University Press.

Plonowska Ziarek, Ewa (2007) 'Melancholic Nationalism and the Pathologies of Commemorating the Holocaust in Poland', in Glowacka, Dorota (ed.) (2007) Imaginary Neighbours. Mediating Polish-Jewish Relations after the Holocaust. Lincoln, NE: Bison Books. Robinson, Hilary (2006) Reading Art, Reading Irigaray: The Politics of Art by Women, London: I. B. Tauris.

Seinfeld Scripts (1989-1998), 'The Visa' (1993), written by Peter Mehlman and transcribed by Dave (ratboy). http://www.seinfeldscripts.com/TheVisa.html. Accessed 18 December 2018. Sholette, Gregory (2011) Dark Matter: Art and Politics in the Age of Enterprise Culture, London: Pluto.

Warner, Marina (2000) [1985]. Monuments and Maidens: The Allegory of the Female Form. Berkeley CA: University of California Press.

\section{LIST OF ILLUSTRATIONS (TBC)}

Fig. 1. Małgorzata Markiewicz, The Resistance Kitchen, 2017, video 3 min 50 s. Video still. Courtesy of the artist.

Fig. 2. Paula Chambers, Domestic Front (2016-), mixed media installation. Installation shot, l'étrangère, 2018. Courtesy of the artist.

Fig. 3. Paula Chambers, Feminist Clutter (2018), mixed media installation. Courtesy of the artist.

Fig. 4. Sera Waters, Boring Conversations \#2: Cloak of Invisibility (front), 2016. Towels, found long stitch, felt, lycra, cotton, variable dimensions. Photograph Grant Hancock.

Fig. 5. Sera Waters, Boring Conversations \#2: Cloak of Invisibility (back), 2016. Towels, found long stitch, felt, lycra, cotton, variable dimensions. Photograph Grant Hancock.

Fig. 6. Sera Waters, Camouflage Cloaks for Invaders: Robe, 2016. Pelt, cotton, leather, heavy duty canvas, wallpaper, brass hooks. Wallpaper: $160 \mathrm{~cm} \mathrm{~h} \mathrm{x} 170 \mathrm{~cm}$ w; Installation: $230 \mathrm{~cm} \mathrm{~h}$ x $170 \mathrm{~cm}$ w. Photograph Grant Hancock. 